\title{
ODYSSEUS AND THE CULT OF APOLLO AT DELOS
}

\author{
Jim Marks* * Earlier versions \\ were presented \\ at the meeting of \\ SBEC in Brasilia, \\ 2013; cf. http:// \\ www.chs-fellows. \\ org/2012/12/06/ \\ odysseus-and-the- \\ cult-of-apollo-at- \\ delos/.
}

\begin{abstract}
This paper explores literary representations of the cult of Apollo on Delos. This island is, to be sure, mentioned only occasionally in early Greek poetry, but details specific to the cult do appear. Thus, for example, Odysseus describes a palm tree he saw at an altar of Apollo on Delos $(\mathrm{Od} .6 .162-3)$, and a third-century inscription from the island mentions just such a feature. References to a palm, altar, and temple at Delos in later classical authors, including Callimachus, Pliny, Cicero, and Plutarch, demonstrate that the Archaic period traditions represented by the Homeric passages continued to shape how successive generations of visitors understood Delos. The material record makes clear that the Greek epic tradition documents a time when Delos was already a well attended sanctuary, and that later constructions at the site attempted to remain consistent with the details preserved in the epics.
\end{abstract}

KEYWORDS: Apollo; Delos; Greek religion; material culture; Odyssey.

\section{ODISSEU E O CULTO A APOLO EM DELOS}

RESUMO: Este artigo explora representações literárias do culto a Apolo em Delos. Esta ilha é, por certo, mencionada apenas ocasionalmente na poesia grega arcaica, mas detalhes específicos do culto aparecem. Assim, por exemplo, Odisseu descreve uma palmeira que ele viu em um altar de Apolo em Delos (Od. 6.162-3), e uma inscrição, do século terceiro, da ilha menciona precisamente tal imagem. Referências a uma palmeira, altar e templo em Delos em autores clássicos posteriores, incluindo Calímaco, Plínio, Cícero e Plutarco, demonstram que as tradições do período arcaico representadas pelas passagens homéricas continuaram a dar forma ao modo como sucessivas gerações de visitantes compreenderam Delos. O registro material torna claro que a tradição épica grega documenta um tempo quando Delos era ainda um santuário bem frequentado, e que construções posteriores no terreno tentaram permanecer consistentes com os detalhes preservados na épica.

PALAVRAS-CHAVE: Apolo; Delos; religião grega; cultura material; Odisseia. 
$\mathrm{M}$ ost early Greek epics seem to have been set in a distant past, in a time long before that in which ancient Greek poets and their audiences lived. By its very nature, then, early Greek epic poetry claimed to bridge the distance between past and present, so that the world of the heroes would come alive in the moment of poetic performance, but also so that the present could be seen as a direct extension of the epic past. Thus, for example, the Trojan War and its aftermath were cited by writers throughout antiquity as an explanation for the political and cultural map of the real ancient Mediterranean world. Conversely, the epics themselves responded to the realities of the world in which their audiences lived, as when the Iliad projects forward to a time long after the Trojan War when all traces of the fortifications of the Greeks have been obliterated (7.443-63, 12.1-34).

This bringing together of past and present was also one of the functions of ancient Greek religious institutions, many of which were designed to preserve in the present sacred practices and locations that were said to have been established in the same mythic past in which many of the epics are set. Indeed, the prestige of an ancient Greek religious site was in some respects directly proportional to its supposed antiquity. In cult as in poetry, the claim to a connection with the distant past is at the same time a claim of authority. To complete the circle, epic poetry in turn claimed to describe important religious centers as they were founded or existed in the heroic past.

It is in this context that I will be discussing how the ancient audiences for Greek epics responded to representations of the cult of Apollo on Delos in epic poetry. This tiny island, which the god shared with his sister Artemis and mother Leto, was one of the two major Panhellenic sanctuaries dedicated to him, the other of course being Delphi. By "Panhellenic," I refer to institutions that were recognized broadly across the ancient Greek world. The Panhellenic character of Apollo's cult on Delos is well demonstrated by the wide geographical range of dedications at the site from the seventh century BCE on. ${ }^{1}$ Its Panhellenic character can also be seen in the fact that the epic tradition set in Delos a competition between the two personifications of Panhellenic epic poetry, Homer and Hesiod. Thus we find in a fragment of the latter the declaration that

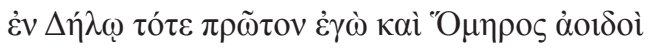

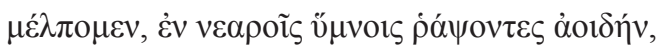

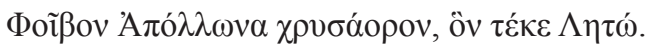

In Delos then for the first time I and Homer, epic performers, we sang, in fresh hymns stitched a song, Phoibos Apollo of the golden sword, whom Leto bore.

$\left(\right.$ Hesiod $357 \mathrm{MW}=$ scholion to Pindar Nemea $\left.2.1^{2}\right)$

\footnotetext{
${ }^{1}$ For a review of the main material evidence for the cult of Apollo on Delos, see Bruneau 1970.

${ }^{2}$ Uncertainties about this fragment are discussed by West 1967; for the purposes of the present argument, however, the precise provenience of fragment $357 \mathrm{MW}$ is irrelevant.
} 
Because Delos was so well known, references to it in the Panhellenic epic poetry of Homer - poetry that, again, was designed to appeal to audiences from many parts of the Greek world - certainly reached the ears of many people who had visited the island and its sacred precinct of Apollo. The fictional representation of Delos would therefore have been constantly juxtaposed with the real-world religious site, for visitors to the small island would naturally be drawn to any monuments referred to in the epics and other contexts, in like manner as modern-day visitors to Greece wish to see Odysseus's Ithake. In what follows, we shall observe ancient authors repeatedly interpreting the monuments of Delos in the light of epic poetry.

To be sure, Delos is mentioned only infrequently in the extant early Greek epic tradition, in an extended scene in the Homeric Hymn to Apollo and in a brief mention in the Odyssey. In the latter poem, Odysseus tells how

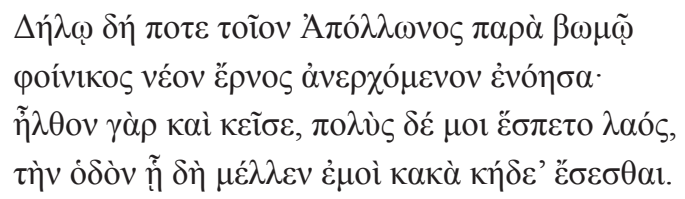

At Delos once such a thing, at the altar of Apollo, the fresh shoot of a palm coming up, did I observe;

For I came even there, and a great crowd accompanied me, on the path by which there were to be so many evil cares in store for me.

(Odyssey 6.162-5)

In this passage, the fame of Delos rests entirely on its connection to the god, though the nature of Odysseus's visit is not made clear. Elsewhere in the epic tradition, the Greeks visit Delos and its king Anios en route to Troy, where they receive a prophecy and the aid of the king's magical daughters, whom the gods blessed with the ability to produce boundless supplies of foodstuffs. ${ }^{3}$ According to another account, Odysseus and Menelaos travel to Delos on a separate mission to obtain these magical daughters. ${ }^{4}$

In any case, the oracular function of Apollo is more usually associated with the god's cult at Delphi, which is also much better documented than Delos, for which reasons it might seem prudent to dismiss any suggestion that Odysseus in the Odyssey consults an oracle at Delos as representing an intrusion of Delphic themes. This is not, however, the only mention of prophecy in connection with Delos by ancient writers. There is on the one hand the evidence of the Aeneid, where Aeneas receives a prophecy at Delus (3.73-130).

\footnotetext{
${ }^{3}$ For the role of Anios and his family in the epic tradition see Kypria F 29 Bernabé with Tsagalis 2008: 44-62.

${ }^{4}$ From a scholium (EPQ, by Aristarchos) to Odyssey 6.164, quoted by Tsagalis 2008: 48.
} 
rex Anius, rex idem hominum Phoebique sacerdos,

uittis et sacra redimitus tempora lauro

occurrit; neterem Anchisen agnouit amicum.

Inngimus hospitio dextras et tecta subimus.

Templa dei saxo nenerabar structa netusto:

Da propriam, Thymbraee, domum; da moenia fessis

et genus et mansuram urbem; serua altera Troiae

Pergama, reliquias Danaum atque immitis Acbilli.

Quem sequimur? Quoue ire iubes? Ubi ponere sedes?

Da, pater, augurium atque animis inlabere nostris.'

Uix ea fatus eram: tremere omnia uisa repente,

liminaque laurusque dei, totusque moneri

mons circum et mugire adytis cortina reclusis.

King Anius, who was at the same time king of men and Phoebus' priest, with the garlands and laurel girding his sacred head, comes forward; he recognized Anchises as an old friend.

We join hands in friendship and enter his abode.

I began venerating the temple of the god, built of ancient stone:

"Grant us our own home, Thymbraean; grant walls to the weary

and a people and city that will endure; preserve another Trojan

Pergamum, the remnants of the Danaans and pitiless Achilles.

Whom do we follow? Where do you bid us to go? Where to establish our abode? Grant, father, a prophecy to enter even our spirits."

Scarcely had I spoken these things; everything seemed to tremble suddenly, the threshold and the god's laurel and all around was moved the mountain, and the cauldrons groaned in their deepest recesses.

(Aeneid 3.80-92)

Here the Trojan hero, in the company of King Anius, makes an inquiry at the "god's temple built of ancient stone" and, as the threshold and the laurels shake, a voice issues forth an enigmatic response. Servius, apropos of another passage from the Aeneid that refers to Delus (ad 4.144), comments that the god offered prophecies during the summer months, and a number of other Roman-era writers, including Lucian and Lucan, refer to oracular consultations at Delos. ${ }^{5}$ From the perspective of Vergil, then, writing in the first century $\mathrm{BCE}$, the temple and its oracle were already a fixed part of the landscape of Delos at the time of the Trojan War (cf. Strabo 10.5.2). The prominence of this temple-oracle complex in the Aeneid can perhaps be explained in part in terms more local to Vergil, specifically with reference to the devastation that the island suffered while under Roman protection during the first century BCE, having been sacked by the troops of Mithridates VI of Pontos in 88, and again by pirates less than twenty years later.

\footnotetext{
${ }^{5}$ Thus, for example, Lucan 6.435 names the tripodas Deli among the oracles consulted by Pompey, and Lucian Alexander 8 refers to wealth accrued by Delos from visitors seeking oracles, cited by Den Adel 1983.
} 
The great antiquity accorded the oracle by Vergil is not entirely consistent with the much earlier Homeric Hymn to Apollo. In this passage, the personification of the island addresses Apollo's mother just before she gives birth to the god:

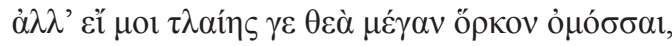

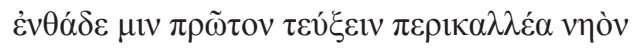

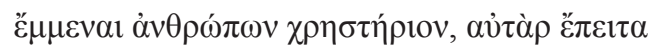

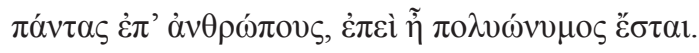

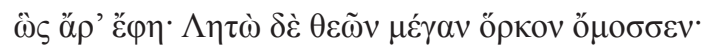

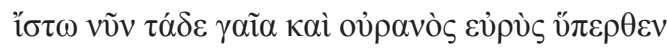

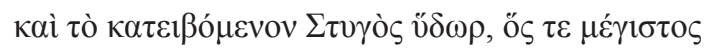

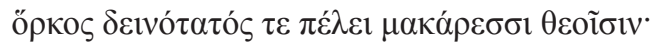

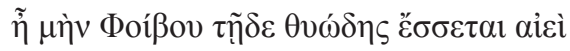

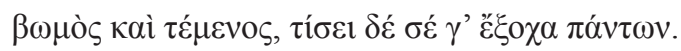

"But if you would venture, goddess, to swear to me a great oath, that here first he will build his very beautiful temple to be an oracle of men, but then for all men, since he will be much-hymned." So she spoke. And Leto swore a great oath of the gods: "Let there be witness now Earth and broad Sky above and the down-dripping water of Styx, which is the greatest oath and most dread for blessed gods:

I swear that here will be always a fragrant altar and sacred precinct, and he will honor you above all."

(Homeric Hymn 3, to Apollo, 79-88)

In the Hymn, the personification of Delos requests, but is not explicitly granted, an oracle (chresterion, 81) at the time of the god's birth, though an altar and a sacred precinct (bomos kai temenos, 88) are explicitly promised at the same time. It would thus appear that the Panhellenic tradition behind this Homeric Hymn acknowledged the possibility of an oracle on the island, but for whatever reason did not accord the oracle the same degree of authority as the altar and precinct. At some point, at least by the Classical period, however, an oracle was indeed active, for a third-century inscription refers explicitly to a manteion. ${ }^{6}$

\footnotetext{
${ }^{6} I G$ 11.2, no. 165, 44; see Bruneau and Ducat 1965: 28, though note that Bruneau 1970: 142-61 expresses some doubt about the official nature of the oracle. The ancient scholar Semos of Delos, who composed a history of the island around $200 \mathrm{CE}$, refers to manteis (FGrH 396 F12), though it is unclear whether these officials were associated with the main cult. Oracles, often ones characterized by novel consultation methods, were a common facet of cults of Apollo generally; thus, for example, responses at the Ismenion at Thebes were deduced from the manner in which sacrifices were consumed by the flames (Herodotus 8.134; cf. Pausanias 9.10.2-3; discussion in Schachter 1981: 81-2).
} 
We are unfortunately uninformed about how those who patronized this oracle may have understood and interpreted the Homeric Hymn and similar traditions.

The oracle of Apollo at Delos, then, was a historical reality, but one that appears not to have maintained as strong a connection to the past as other aspects of the god's cult on the island. Perhaps because it became overshadowed by Delphi in this capacity, Delos is not accorded authority as a prophetic center in the Homeric Hymn. Later writers, such as Vergil, however, found other sources of authority - presumably regional narratives or non-Homeric epics - that established an ancient pedigree for the tradition of prophecy on Delos. This tradition seems to have prevailed, and to have become part of the landscape of the heroic past. Thus, by way of further example, Pausanias records the tradition that the island was once visited by one of the prophetic priestesses known as Sibyls, specifically one who had interpreted the dream of Hekabe, wife of Priam (10.12.5).

But let us return to what Odysseus actually says about Delos in the Odyssey. For the hero alludes to a very specific aspect of Apollo's cult on the island when he mentions a palm tree, or phoinix in Greek. According to the god's birth-narrative as related in the Homeric Hymn, his mother Leto leaned against a phoinix when overcome by labor pains.

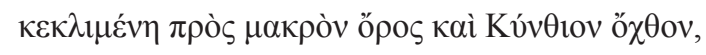

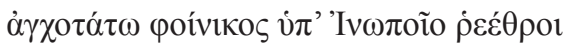

having reclined facing the great Cynthian mountain and hill up against a palm tree by the flows of Inopous

$\cdots$

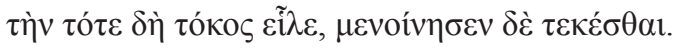

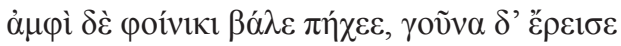

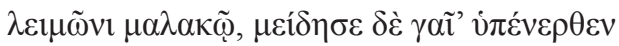

Indeed then labor took hold of her, and she longed to give birth, and she cast her arm around a palm tree, and supported her knees on the soft meadow, and Earth smiled beneath.

(Homeric Hymn 3, to Apollo, 17-8; 116-8)

I draw particular attention to the fact that, in the first passage here, the palm is part of a description of the landscape that includes the Cynthian hill and stream of Inopos that were associated with Apollo's sacred precinct on Delos. ${ }^{7}$ The specificity of the allusion is further suggested by the fact that there is, to my knowledge, no other context in the epic

\footnotetext{
${ }^{7}$ For the connection between the palm reference here at Odyssey 6.163 and the cult of Leto see Crielaard 1995: 257; for the function of the palm tree in the rhetoric of Odysseus at this point in the Odyssey see Harder 1988. Sourvinou-Inwood 1985:125 declares that "there are to my knowledge no representations of the 'altar + palm tree' that can be convincingly shown to be associated with a deity other than Apollo, Artemis, Leto, or (less frequently, and almost certainly through the connection with Apollo and Delphi) Dionysos."
} 
tradition apart from Delos in which a palm tree is mentioned. The tree is thus a symbol of the special relationship among the god, his divine mother and sister, and the place of his birth. ${ }^{8}$ The Odyssey places this potent symbol in physical proximity to the god's altar, and the Homeric Hymn integrates it into the Delian landscape.

In antiquity, the Delian palm tree of epic was identified with one or more actual trees in Apollo's sacred precinct on Delos. Thus, for example, Callimachus invokes a palm tree in order to establish the Delian setting for his Hymn to Apollo:

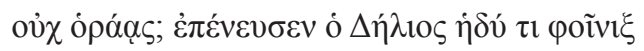

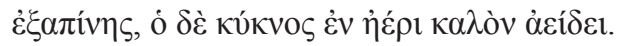

Do you not see? The Delian palm nods pleasantly

of a sudden, and the swan in the air sings sweetly.

(Callimachus Hymn 2 (eis Apollona) 4-5)

The tree's natural characteristics were thought to explain its survival from the heroic past all the way until the time of historical Greek and Roman writers. Thus Theophrastus cites the Delian palm, along with sacred olives at Athens and Olympia and other trees said to date from the Trojan War, as evidence of the extreme longevity, makrobiotes, of certain plants:

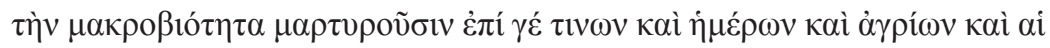

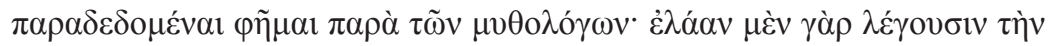

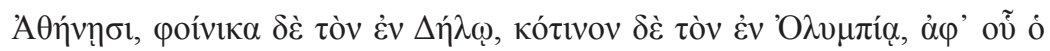

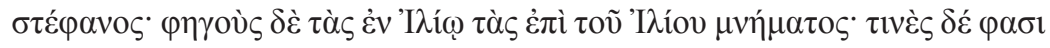

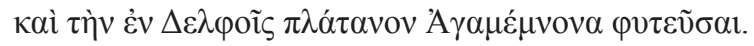

To the longevity of some plants, both cultivated and wild, witness is borne also in the stories handed down by the mythographers; for they speak of the olive at Athens, the palm in Delos, and the wild olive at Olympia that is the source of the wreath, and the oaks at Ilion on the tomb of Ilios; and they say that Agamemnon planted the plane tree at Delphi.

(Theophrastus Peri Phutōn Historias 4.13.2)

These sentiments are echoed by Pliny, who appears to date the Delian palm to the time of Apollo's advent there (ab eiusdem dei [Apollo] aetate, Historia Naturalis 16.89). A character in one of Cicero's dialogues similarly states that, even in his day, a palm said to be the one referred to by Ulysses in the Odyssey was still on display:

quam Homericus Vlixes Deli se proceram et teneram palmam uidisse dixit, hodie monstrant eandem, multaque alia multis locis diutius commemoratione manent quam natura stare potuerunt.

\footnotetext{
${ }^{8}$ Ahl 1982: 381-3, 408-10 discusses the lunar imagery that connects Leto and the phoinix.
} 
The palm of Delus that Homer's Ulysses said that he had seen, tall and slender, this same palm they point out today, and so with regard to other things, in many places, the memory of which endures longer than they were able to remain by their nature.

(Cicero De Legibus 1.1.2)

Of course, Odysseus refers to a young palm shoot, which logically would not be the same plant against which Leto leaned while giving birth to Apollo many (mythical) generations earlier, but the two blurred into one another. This is hardly surprising; one can imagine the difficulty of keeping two famous old palm trees distinct in one precinct of Apollo.

The image of one or more palm trees at Delos, then, links the heroic past with the religious observances of the present, which observances in turn look to the heroic past for authority. ${ }^{9}$ The birthplace of Apollo is rendered tangible, its past brought literally alive, in the form of the still-living tree. As Cicero's character observes, this kind of immortality, or at least extreme longevity, is a product of the interaction between the physical space where the god is worshipped on the one hand, and the poetry that claims to preserve the memory of the original emergence of that space on the other. The answer to a question regarding the Delian palm that is posed in Cicero's dialogue, "how can poets sow immortal trees?", is that only the commemorative function of poetry can distinguish the true nature of the monuments associated with a religious site, and thus the site itself, from the profane and undifferentiated bulk of the physical world that is not the god's special preserve.

The intersection of historical and poetical identity of course occurs in the case of constructed monuments as well as living things like trees, and it is in this context that I turn now to another feature in Odysseus's brief description of Delos, namely the altar, bomos, with which the palm is associated (Odyssey 6.162). The epic tradition seems to invite identification of this altar with the one that, as has been seen, is promised to Delos during the island's negotiations with Leto (Homeric Hymn 3.88). To be sure, altars are common features of religious sites generally in ancient Greek literature-for example, Apollo's shrines at Chryse (Iliad 1.440) and Pagasae (Aspis 70) are similarly equipped with a bomos, as are numerous cult sites of other gods. Yet it is also a fact that, at some point, Delos became home to a specific altar that was famed throughout the ancient world.

I am of course speaking of the keraton, the "Altar of Horns," immortalized for instance by Callimachus elsewhere in his Hymn to Apollo (2.60-4): ${ }^{10}$

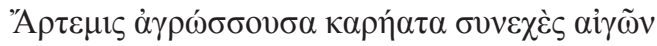

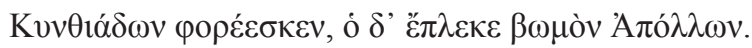

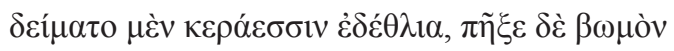

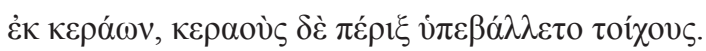

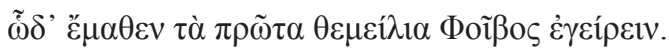

\footnotetext{
${ }^{9}$ Note in this context that the Athenian politician Nikias is said to have dedicated a bronze palm on Delos (Plutarch Nikias 3.7).

${ }^{10}$ For overviews of ancient references to the altar, see Bruneau 1970: 26-8 and Bethe 1937.
} 
Artemis from her hunting continually the heads of goats, Cynthian ones, kept bringing, and Apollo wove an altar.

He measured out the foundations with horns, he fashioned an altar of horns, of horn were the walls he cast around.

In this way Phoibos learned to raise up the first foundations.

(Callimachus Hymn 2, to Apollo, 60-4)

Particularly significant in this context is the testimony of Plutarch, who numbers keraton among the Seven Wonders of the World.

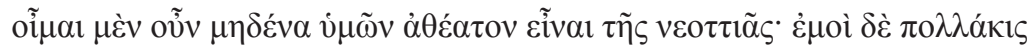

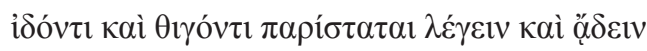

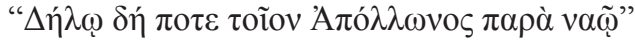

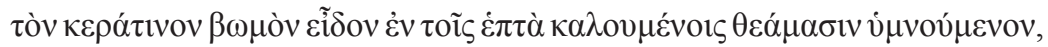

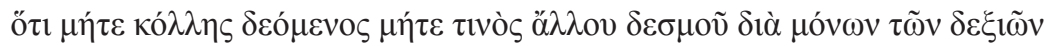

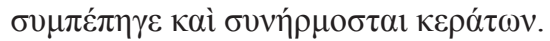

I suppose none of you has failed to notice this nest [of the halcyon bird]; as for me, whenever I have had the opportunity to see or touch it, I am minded to say and sing,

"Once such a thing in Delos at the shrine of Apollo." [ Odyssey 6.162] I saw the Altar of Horns, sung of as one of the Seven Wonders because it needs no glue or any other binding, but has been pegged and is fastened together entirely of horns taken from the right side of the head.

(Plutarch Moralia / De sollertia animalium 983e)

Plutarch's discussion of the altar occurs apropos of a description of the halcyon bird: its nest, which is said to be constructed without any binding material, brings to mind the similarly-constructed keraton and with it the quotation from the Odyssey. Thus, in the case of the altar as with the palm tree, ancient writers continued to refer to the early Greek epic tradition when thinking about the contemporary site of Delos.

The keraton was, as the testimony of Callimachus attests, a well-known feature of Delos at least by the third century BCE. But regardless of when the altar was actually first constructed, it was or became identified with the one referred to in the early epics. Not surprisingly, this conspicuous landmark was said to have been the place where Homer first sang his Hymn to Apollo. ${ }^{11}$

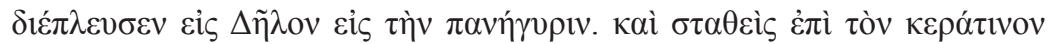

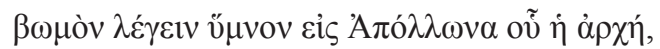

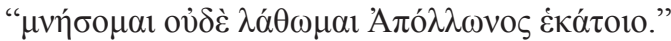

\footnotetext{
${ }^{11}$ Nagy 2010: 51.
} 
He [Homer] sailed to Delos for the gathering. And having stood at the Altar of Horns, he speaks the Hymn to Apollon, the beginning of which is, "I shall remember and let me not forget Apollo the far-shooter."

(Contest of Homer \& Hesiod, 315-8 Allen)

Like the palm tree, the altar of Apollo at Delos connects the epic past with the sacred precinct where the god's worshippers assembled regularly for generation after generation in order to pray, sacrifice, dance and sing, compete in games, and, perhaps, to seek prophecy. We may compare the description of the festival of the Ionians in the Homeric Hymn to Apollo (133-81): this well-know passage, familiar to many from a quotation by Thucydides (3.104), associates the figure of Homer with the dances and games that were staged during actual religious ceremonies, and in so doing confers Panhellenic authority on the Delian festival. ${ }^{12}$ In like manner, the references to the bomos in the Odyssey and Homeric Hymn came naturally to be identified with the keraton, even if no keraton existed at the time these poems were taking shape. It was at this specific altar that, again to complete the circle, Homer was said to have performed his hymn for the god.

The keraton itself is in fact mentioned in heroic contexts outside the mainstream Homeric and Hesiodic traditions. Thus Plutarch elsewhere relates the story that Theseus, on his return from Crete, stopped at Delos in order to sacrifice to Apollo, in the course of which visit he and his men performed the famous "crane-dance" around the keraton: 13

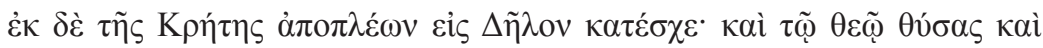

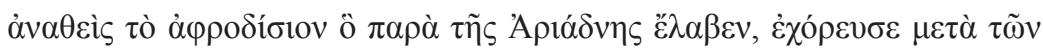

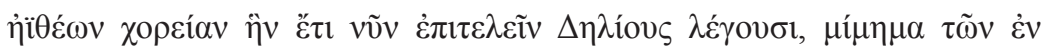

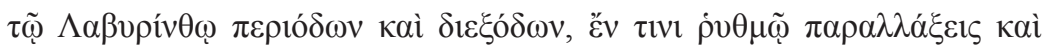

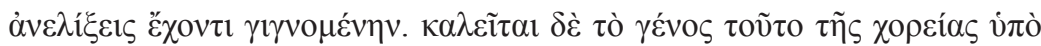

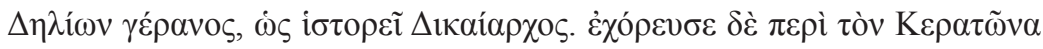

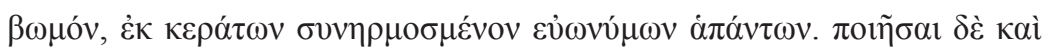

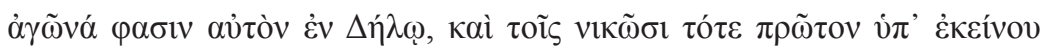

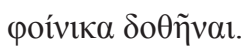

On his voyage from Crete, Theseus stopped at Delos and, after sacrificing to the god and dedicating in the temple the image of Aphrodite that he took from Ariadne, he danced with his demigods a dance that they say the Delians still perform, being an imitation of the passages in the Labyrinth that go forward and back. This kind of dance, as Dikaiarchos tells us, is called "the crane" by the Delians, and Theseus danced it round the Keraton Altar, which

\footnotetext{
${ }^{12}$ See for example Nagy 2010: 218-23.

${ }^{13}$ See also Pollux 4.101; passages are discussed by Burns 1974: 7-8.
} 
is made of horns taken entirely from the left ${ }^{14}$ side of the head. They say that he also instituted an athletic contest in Delos, and initiated the custom of giving a palm to the victors.

(Plutarch, Theseus 21.1-2)

It therefore seems that mention of Delos prompted the image of the island's famous altar, in like manner as mention of Rio prompts the image of the Cristo Redentor. By way of a contrasting example, the Iliad refers to a bomos of Apollo at Chryse in the Troad (1.440), which altar, even if it actually existed, would have been visited by relatively few people. As a consequence, most, if not all, ancient Greeks who were familiar with this Iliadic passage would have had to supply some generic conception of "altar" when visualizing the scene. In the case of the bomos at Delos in the Odyssey and Homeric Hymn, by contrast, a highly conspicuous referent existed in the form of the real-world keraton.

These considerations naturally raise the question of how the representation of Delos in ancient literature compares with the material record of the site. As has been seen, the Odyssey speaks of a well-established sanctuary of Apollo that caters to worshippers from the other side of the Greek world (i.e., Odysseus and his men), and the Homeric Hymn refers to regional worshippers, the Ionians who hold the Delian festival (147). These literary representations of the sanctuary include the palm and altar, as well as a temple that is mentioned in the Hymn. In sum, it can at the very least be said that these poems must have taken the forms in which we know them at a time when the cult of Apollo was already well established on Delos, with a festival and games, a time when the site had already become monumentalized and was already attracting a Panhellenic constituency.

The archaeological record of Delos shows some evidence of human activity in the Bronze Age, including a pair of Mycenaean graves, but the island did not start to become an important center of cult until the eighth century. The votive offerings serve to establish the point at which the site began to assume Panhellenic significance. At first, only Athens is represented beyond the Cyclades, but by 700 BCE imports from Rhodes, Corinth, Euboia, Crete and even Cyprus begin to appear. ${ }^{15}$ The first temples on Delos also date to this period. Interestingly, they appear to have been dedicated to the goddesses Artemis and Hera, though it is possible that another contemporary building ("Building $\Gamma$ ") was dedicated to Apollo. ${ }^{16}$ Here the selectivity of the literary record is noteworthy, for, as we have seen, the precedence of Apollo in ancient discussions of the site is unquestioned. An obvious comparison is

\footnotetext{
${ }^{14}$ Note the inconsistency in the tradition regarding which horn (right or left) was taken from the goats to serve as raw material for the altar.

${ }^{15}$ Constantakopoulou 2007: 39-41; Morgan 1990: 206 attributes the diversity of dedications at Delos at least in part to "travelling craftsmen." Further discussion in Snodgrass 1980: 53, 56-7.

${ }_{16}$ Mazarakis Ainian 1997: 179-83 discusses the remains of the early cult buildings. Coldstream 2003 [1977]: 213-6 notes that no temple of Apollo has been identified from the Geometric period or earlier, though he is convinced that by 700 the god had become "lord of Delos" (330). See also Clement Exhortations 3.
} 
Olympia, where the early dominance of Hera in the material record contrasts with the dominance of Zeus in the literary record. ${ }^{17}$

It therefore appears that the precedence of Apollo over Artemis and Leto correlates with the increasingly Panhellenic orientation of Delos. The Panhellenic orientation of the literary texts is also interesting given the fact that the nearby island of Naxos seems to have been responsible for a particularly large amount of the construction and votives on Delos in the seventh century and early sixth centuries. ${ }^{18}$ The literary record, however, shows no awareness of this fact, from which silence we may infer that the Naxians' claims to special privileges apparently failed to make an impression upon—or may alternatively been effaced from-the Panhellenic conception of Delian Apollo.

Various and conflicting identifications of the temple that is promised to Delos by Leto in the Homeric Hymn have been proposed by modern scholars. ${ }^{19}$ In analyzing the literary record, however, it would be a mistake to try to identify one specific monument at one specific moment, for the Hymn identifies any and all religious buildings on the island at any given time as part of a construction program that began with the encounter between Leto and Delos. Similar is the case with the Altar of Horns: while the one mentioned by Hellenistic and later writers has been identified with a building of the Classical period, known as GD 39 , this structure was in turn likely designed to upgrade or to replace an earlier altar. ${ }^{20}$ As discussed, once the Delian altar began to become famous, anyone with knowledge of it would naturally identify this altar with the one mentioned in the epics.

The historical cult of Apollo at Delos before the seventh century was, then, not firmly established, or at least had not yet come to supersede the cults of Artemis and Hera on the island. Put another way, the picture that emerges from the epics - of a time when Delos had become home to a widely-attended festival dedicated almost exclusively to Apollo, a time when the island was a place that a hero from the other side of the Greek world would visit, and when it featured a temple dedicated to the god - such a picture would be completely anachronistic before 700 BCE. Indeed, taking into account the time required for this conception of Delos to become embedded in the epic tradition, the Panhellenic orientation of the site attested in the Odyssey and Homeric Hymn would seem to fit more comfortably into a mid- or even late-seventh century context.

Again, it is not entirely clear precisely when the keraton, let alone special palm trees, became part of the sacred landscape of Delos. The myth that Apollo himself constructed the altar that appears for instance in Callimachus (Hymn 2.60-4) is an obvious attempt to assign the Altar of Horns, and the cult of the god, to the earliest phase of worship on the island. By the time Callimachus speaks of this altar, this myth has become established: the

\footnotetext{
${ }^{17}$ The chronological sequence of temple construction at Olympia is summarized by Morgan 1990: 133.

${ }^{18}$ Constantakopoulou 2007: 43-6; as she notes, "It is possible to claim that the Naxians were using Delos as a showroom for conspicuous exhibition of their artistic development and wealth, but monumentalization and art do not necessarily imply political domination or imperial control."

${ }^{19}$ For a survey of opinions see Constantakopoulou 2007: 43 n.42.

${ }^{20}$ Bruneau and Fraisse 2002.
} 
keraton has been there ever since the god built it, and any visitor to the island in the heroic age, Odysseus, Theseus, and so on, is assumed to have visited it.

Mythical history and the texts in which it was preserved thus existed in a dynamic relationship with monuments that were visible in various forms to successive generations of ancient worshippers. As in a movie in which a character travels back in time and makes some change in the course of history, the fame of the keraton in a sense travels back in time to rewrite the ancient epic tradition. So also with the palm tree to which Cicero, Plutarch and other later writers refer and the temple promised to the personified Delos in the Homeric Hymn: visitors to the island were presented with monuments that brought to life the images preserved in epic poetry. These poetic images, in turn, were constantly reinterpreted as the god's birthplace continued to evolve.

\section{WORKS CITED}

AHL, Frederick. Amber, Avallon, and Apollo's Singing Swan. American Journal of Pbilology, v. 103, n. 4, p. 373-411, 1982.

BETHE, Erich. Das Archaische Delos und sein Letoon. Hermes, v. 72, n. 2, p. 199-201, 1937.

BRUNEAU, Philippe; FRAISSE, Philippe. Le monument à Abside et la question de l'Autel de cornes. Exploration archéologique de Délos. Fascicule XL. École Française d'Athènes, 2002.

BRUNEAU, Philippe. Recherches sur les Cultes de Délos a l'Epoque Hellénistique et a l'Epoque Impériale. Paris: Éditions de Boccard, 1970.

BRUNEAU, Philippe; DUCAT, Jean. Guide de Délos. Paris: Éditions de Boccard, 1965.

BURNS, Alfred. The Chorus of Ariadne. Classical Journal, v.70, n. 2, p. 1-12, 1974.

COLDSTREAM, John Nicolas. Geometric Greece: 900-700 BC. London: Routledge, 2003 [1977].

CONSTANTAKOPOULOU, Christy. The Dance of the Islands: Insularity, Networks, the Athenian Empire and the Aegean World. Oxford: Oxford University Press, 2007.

CRIELAARD, Jan. Homer, History and Archaeology: Some Remarks on the Date of the Homeric World. In: CRIELAARD, J. (ed.). Homeric Questions. Amsterdam, 1995, p. 201-88.

DANEK, Georg. Epos und Zitat: Studien zu den Quellen der Odyssee. Vienna, 1998.

DEN ADEL, Raymond. Apollo’s Prophecies at Delos. Classical World, v. 76, n.5, p. 288-90, 1983.

HARDER, R. Nausikaa und die Palme von Delos. Gymnasium, v. 95, p. 505-16, 1988.

MAZARAKIS AINIAN, Alexander. From Rulers' Dwellings to Temples: Architecture, Religion and Society in Early Iron Age Greece (c. $1100-700$ B.C.). Studies in Mediterranean Archaeology, v. CXXI. Jonsered: Paul Asströms förlag, 1997. 
MORGAN, Catherine. Athletes and Oracles: the Transformation of Olympia and Delphi in the eighth century BC. Cambridge: Cambridge University Press, 1990.

NAGY, Gregory. Homer the Preclassic. Berkeley; Los Angeles CA: University of California Press, 2010.

SCHACHTER, Albert. Cults of Boiotia, v. 1. Acheloos to Hera. Bulletin of the Institute of Classical Studies, London, Institute of Classical Studies, v. 28, suppl. 38-1, 1981.

SNODGRASS, Anthony. Archaic Greece: the Age of Experiment. Berkeley CA: University of California Press, 1980.

SOURVINOU-INWOOD, Christiane. Due protettrici della donna a Locri Epizefirii: Persefone e Afrodite. In: ARRIGONI, Giampiera (a cura di). Le donne in Grecia. Roma-Bari: Laterza, 1985, p. 203-221.

TSAGALIS, Christos. The Oral Palimpsest: Exploring Intertextuality in the Homeric Epics. Cambridge MA: Harvard University Press, 2008.

WEST, Martin. The Contest of Homer and Hesiod. Classical Quarterly New Series, v. 17, n. 2, p. 433-50, 1967. 